\title{
Synthesis of Novel Quaternary Ammonium Salts and Their in Vitro Antileishmanial Activity and U-937 Cell Cytotoxicity
}

\author{
Sandra M. Duque-Benítez ${ }^{1}$, Luz Amalia Ríos-Vásquez ${ }^{1, *}$, Rogelio Ocampo-Cardona ${ }^{1}$, \\ David L. Cedeño ${ }^{2,+}$, Marjorie A. Jones ${ }^{2}$, Iván D. Vélez ${ }^{3}$ and Sara M. Robledo ${ }^{3, *}$ \\ 1 Department of Chemistry, Universidad de Caldas, AA275 Manizales, Colombia; \\ samidube@gmail.com (S.M.D.-B.); rogelio.ocampo@ucaldas.edu.co (R.O.-C.) \\ 2 Department of Chemistry, Illinois State University, Normal, 61790 IL, USA; daleceme@gmail.com (D.L.C.); \\ majone3@ilstu.edu (M.A.J.) \\ 3 PECET, Medical Research Institute, School of Medicine, University of Antioquia, 0500100 Medellín, \\ Colombia; ivan.velez@udea.edu.co \\ * Correspondence: amalia.rios@ucaldas.edu.co (L.A.R.-V.); sara.robledo@udea.edu.co (S.M.R.); \\ Tel.: +57-311-733-9680 (L.A.R.-V.); +57-304-576-2059 (S.M.R.) \\ + Present/Permanent Address: Millennium Pain Center, Basic Science, Bloomington, 61701 IL, USA.
}

Academic Editor: Alessandro Palmieri

Received: 25 February 2016 ; Accepted: 14 March 2016 ; Published: 29 March 2016

\begin{abstract}
This work describes the synthesis of a series of quaternary ammonium salts and the assessment of their in vitro antileishmanial activity and cytotoxicity. A preliminary discussion on a structure-activity relationship of the compounds is also included. Three series of quaternary ammonium salts were prepared: (i) halomethylated quaternary ammonium salts (series I); (ii) non-halogenated quaternary ammonium salts (series II) and (iii) halomethylated choline analogs (series III). Assessments of their in vitro cytotoxicity in human promonocytic cells U-937 and antileishmanial activity in axenic amastigotes of L. (Viannia) panamensis (M/HOM/87/UA140-pIR-eGFP) were carried out using the MTT (3-(4,5-dimethylthiazol-2-yl)-2,5-diphenyl-tetrazolium bromide) micromethod. Antileishmanial activity was also tested in intracellular amastigotes of $L$. $(V)$ panamensis using flow cytometry. High toxicity for human U937 cells was found with most of the compounds, which exhibited Lethal Concentration $50\left(\mathrm{LC}_{50}\right)$ values in the range of 9 to $46 \mu \mathrm{g} / \mathrm{mL}$. Most of the compounds evidenced antileishmanial activity. In axenic amastigotes, the antileishmanial activity varied from 14 to $57 \mu \mathrm{g} / \mathrm{mL}$, while in intracellular amastigotes their activity varied from 17 to $50 \mu \mathrm{g} / \mathrm{mL}$. $N$-Chloromethyl- $N, N$-dimethyl- $N$-(4,4-diphenylbut-3-en-1-yl)ammonium iodide (1a), $\mathrm{N}$-iodomethyl- $\mathrm{N}, \mathrm{N}$-dimethyl- $\mathrm{N}$-(4,4-diphenylbut-3-en-1-yl)ammonium iodide (2a), $\mathrm{N}, \mathrm{N}, \mathrm{N}$-trimethyl$\mathrm{N}$-(4,4-diphenylbut-3-en-1-yl)ammonium iodide (3a) and $\mathrm{N}, \mathrm{N}, \mathrm{N}$-trimethyl- $\mathrm{N}$-(5,5-diphenylpent-4-en1-yl)ammonium iodide ( $3 \mathbf{b})$ turned out to be the most active compounds against intracellular amastigotes of $L$. $(V)$ panamensis, with $\mathrm{EC}_{50}$ values varying between 24.7 for compound $\mathbf{3 b}$ and $38.4 \mu \mathrm{g} / \mathrm{mL}$ for compound 1a. Thus, these compounds represents new "hits" in the development of leishmanicidal drugs.
\end{abstract}

Keywords: leishmaniasis; halomethylated quaternary ammoniun salts; halomethylated choline analogs; Leishmania (V) panamensis; antileishmanial activity; cytotoxicity

\section{Introduction}

Leishmaniasis is an infectious disease caused by trypanosomatid parasites of the Leishmania genus. At least 20 Leishmania species are known to cause different clinical forms of leishmaniasis in humans and they are present in different locations worldwide [1]. There are three main clinical 
manifestations: visceral (VL), mucocutaneous (ML), and cutaneous leishmaniasis (CL), respectively. These vary according to the Leishmania species, the geographical region, and the host's immune response. Leishmaniases are endemic in 98 countries over five continents, with CL being the most prevalent around the world. It is estimated that 12 million people are infected, with 0.7 to 1.2 million new cases occurring every year and 350 million people at risk of infection [2]. The disease disproportionately affects economically and socially disadvantaged people and causes psychological suffering due to the social stigma associated to it [3]. Considering that an effective vaccine is not yet available to protect against leishmaniasis [4], most current research aims at finding alternative treatments of the illness. This has been focused on the development of improved chemotherapies because current medications are not fully satisfactory. Pentavalent antimonials, such as meglumine antimoniate (MA) or sodium stibogluconate are the most widely used antileishmanial drugs, while other medications including pentamidine isothionate, miltefosine, and amphotericin B (AmB) are also available. Although these are reasonably effective, they have serious side effects and require prolonged treatments. Additionally, Leishmania parasites are increasingly developing resistance. Altogether, these drawbacks are affecting the adherence of patients to treatments [5]. On the other hand, pharmaceutical companies have demonstrated little motivation to invest in the generation and production of new treatments, thus, since 2002 leishmaniasis has been considered a neglected disease by the World Health Organization [6]. Therefore, academic centers have taken the challenge to investigate and develop therapies that are more accessible, safer, easier to administer, while more effective at low dose with short-length treatments, and at a reasonable cost.

It is well known that certain quaternary ammonium salts are widely used by the pharmaceutical industry for their recognized activity against fungi, bacteria, viruses and parasites. For example, there are reports on their antimicrobial activity against Cryptococcus neoformans, Candida albicans, Saccharomyces cerevisiae, Aspergillus fumigatus, A. niger, Mucor mucedo [7,8]. Human immunodeficiency virus-1 [9], Staphylococcus aureus, Streptococcus faecalis, Escherichia coli, Proteus vulgaris [8], Plasmodium falciparum [10], L. donovani and L. infantum [11,12].

Miltefosine (hexadecylphosphocholine), a particular example of a quaternary ammonium salt bearing an apolar C16 chain and a phosphoester group, was initially used as antitumor drug and subsequently was approved for the oral treatment of both cutaneous and visceral leishmaniasis [13,14]. Its biochemical mechanism of action, however, is only partially known. It is generally accepted that the biosynthesis of phosphatidylcholine in Leishmania spp. parasites is strongly dependent on choline [15]; thus, quaternary ammonium salts, acting as choline structural analogs, might reduce the content of phosphatidylcholine and phosphatidyl ethanolamine of the parasites, metabolites that are important to synthesize and preserve the structure of the lipid membranes of eukaryotic cells [16].

Based on the fact that the biosynthesis of phosphatidylcholine in Leishmania spp. parasites is strongly dependent on choline [15], and on the in vitro and in vivo antileishmanial activity demonstrated by quaternary ammonium salts such as edelfosine, ilmofosine and miltefosine [17], a series of $N$-halomethylated quaternary ammonium salts with C4 or C5 side chains bearing monophenyland biphenyl-substituted double bonds (Figure 1) were screened in vitro as potential antileishmanial agents. The screening revealed that these compounds are active against promastigotes of L. tarentolae (unpublished data). Although L. tarentolae is a Leishmania species that affects certain reptiles but does not infect humans, it has been demonstrated that L. tarentolae offer a suitable model during the in vitro screening of compounds for activity against Leishmania parasite and the identification of compounds with potential as antileishmanial drugs [18].

In this work, various series of quaternary ammonium salts were prepared with the purpose to advance in the identification of "hit" and "lead" compounds as potential candidates for new antileishmanial agents, and trying to establish a possible structure-activity relationship on leishmanicidal activity, especially the effect of the chain length and the presence or absence of a halogen in place of one of the hydrogens of the $N$-methyl. Thus, three series of quaternary ammonium salts were prepared: (i) halomethylated quaternary ammonium salts $\mathbf{1}$ and $\mathbf{2}$ (series I), (ii) non-halogenated 
quaternary ammonium salts 3 (series II) and (iii) halomethylated choline analogs 4 a and 4 b (series III). The assessment of their in vitro cytotoxicity in the human promonocytic U-937 cell line and their antileishmanial activity in axenic and intracellular amastigotes of L. (V) panamensis was performed, taking into account that this parasite is one of the most pathogenic species for humans in the Americas.

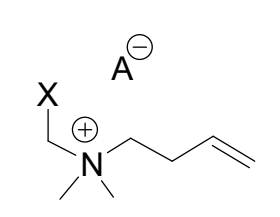

$$
\begin{array}{r}
5 \mathbf{a}: X=I, A=\mathrm{BF}_{4}^{-} \\
\mathbf{b}: X=\mathrm{Br}, \mathrm{A}=\mathrm{Br}^{-}
\end{array}
$$

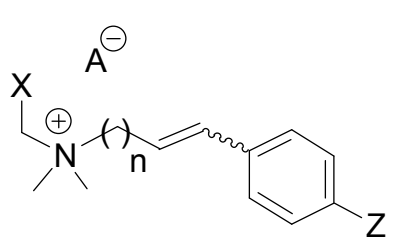

$$
\begin{aligned}
& 6 \text { a : } n=3, X=I, A=B F_{4}^{-}, Z=H \\
& \text { b : } n=2, X=B r, A=B_{4}{ }^{-}, Z=H \\
& \text { c: } n=3, X=I, A=B F_{4}^{-}, Z=O_{3} \\
& \text { d: } n=3, X=I, A=B_{4}^{-}, Z=\mathrm{CH}_{3} \\
& \text { e : } n=3, X=1, A=B_{4}{ }^{-}, Z=C l \\
& \text { f: } \mathrm{n}=3, \mathrm{X}=\mathrm{I}, \mathrm{A}=\mathrm{BF}_{4}^{-}, \mathrm{Z}=\mathrm{CF}_{3}
\end{aligned}
$$

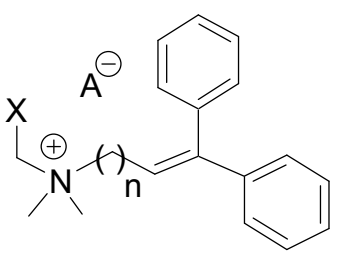

$$
7: \mathrm{n}=3, \mathrm{X}=\mathrm{I}, \mathrm{A}=\mathrm{BF}_{4}^{-}
$$

Figure 1. Compounds screened for in vitro efficacy against Leishmania tarentolae parasites.

\section{Results}

\subsection{Synthesis}

Eleven compounds (1, 2, 3, 4a and 4b) and choline 4c were prepared (Schemes 1 and 2). Eight of them are new: $N$-chloromethyl- $N, N$-dimethyl- $N$-(4,4-diphenyl-3-buten-1-yl)ammonium iodide (1a), $N$-chloromethyl- $N, N$-dimethyl- $N$-(5,5-diphenyl-4-penten-1-yl)ammonium iodide (1b), $N$-chloromethyl- $N, N$-dimethyl- $N$-(6,6-diphenyl-5-hexen-1-yl)ammonium iodide (1c) $N$-iodomethyl- $N$, $N$-dimethyl-N-(4,4-diphenyl-3-buten-1-yl)ammonium iodide (2a), $N$-iodomethyl- $N, N$-dimethyl- $N$ (6,6-diphenyl-5-hexen-1-yl)ammonium iodide (2c), N,N,N-trimethyl-N-(4,4-diphenyl-3-buten-1-yl)ammonium iodide (3a), N,N,N-trimethyl-N-(5,5-diphenyl-4-penten-1-yl)ammonium iodide (3b) and $N, N, N$-trimethyl-N-(6,6-diphenyl-5-hexen-1-yl)ammonium iodide (3c). The other three: $N$-iodomethyl-N,N-dimethyl-N-(5,5-diphenyl-4-penten-1-yl)ammonium iodide (2b), N-chloromethyl$N$-(2-hydroxyethyl)- $N, N$-(dimethyl)ammonium iodide (4a) and $N$-(2-hydroxyethyl)- $N$-iodomethyl- $N$, $N$-dimethyl)ammonium iodide $(4 \mathbf{b})$, are known compounds.

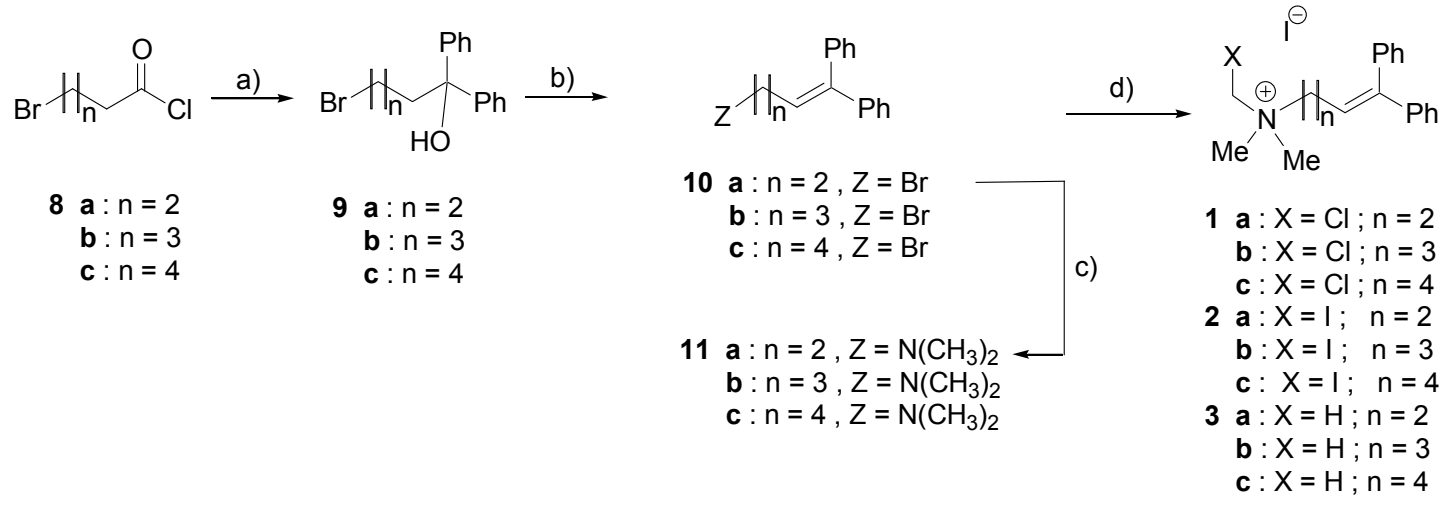

Reagents and conditions: a) $\mathrm{PhMgBr}\left(2.5 \mathrm{eq}\right.$ ), dry ether, $0^{\circ} \mathrm{C}$ to r.t; b) TsOH. $\mathrm{H}_{2} \mathrm{O} 1.5 \%$ molar, benzene, reflux, $6 \mathrm{~h}$. c) $40 \%$ aqueous $\left(\mathrm{CH}_{3}\right)_{2} \mathrm{NH}$ (25 eq of amine), r.t $24-48$ h. d) $\mathrm{XCH}_{2} \mathrm{I}$ where X=H, Cl or I (4.0 eq), acetonitrile, r.t, $24 \mathrm{~h}$.

Scheme 1. Synthesis of quaternary ammonium salts 1, 2 and 3 (series I and II). 


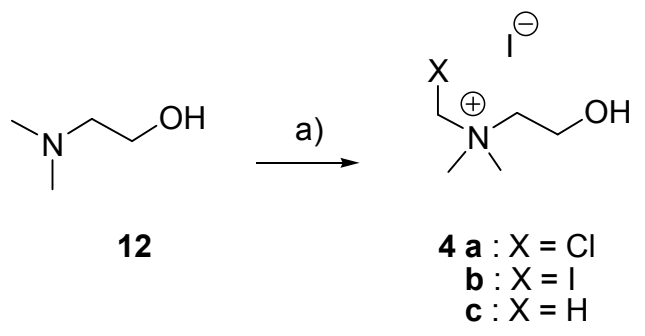

Reagents and conditions: a) $\mathrm{XCH}_{2} \mathrm{I}$ (with $\mathrm{X}=\mathrm{Cl}$, I or $\mathrm{H}$ ), THF, stirring in the dark for $24 \mathrm{~h}$.

Scheme 2. Synthesis of choline $4 \mathbf{c}$ and choline analogs $4 \mathbf{a}$ and $\mathbf{4 b}$.

Compounds $\mathbf{1 a}, \mathbf{1} \mathbf{b}, \mathbf{1} \mathbf{c}, \mathbf{2} \mathbf{a}, \mathbf{2} \mathbf{b}, \mathbf{2} \mathbf{c}, \mathbf{3 a}, \mathbf{3 b}$ and $\mathbf{3 c}$ were prepared according to the sequence shown in Scheme 1, following or adapting literature methods [18,19] from $\omega$-bromoacyl chlorides 8 by a four-step sequence involving: (i) a Grignard reaction to obtain $\omega$-bromo- $\alpha, \alpha$-diphenyl alcohols 9 with yields ranging from $68 \%$ to $78 \%$; (ii) an acid-catalized dehydration of alcohols 9 using $p$-toluenesulfonic acid in benzene to form the corresponding $\omega$-bromo- $\alpha, \alpha$-diphenyl olefins 10 with yields beteween $82 \%$ and $90 \%$; (iii) a nucleophilic displacement of bromide from the $\omega$-bromo- $\alpha, \alpha$-diphenyl olefins 10 by dimethylamine to produce $\omega$-(N,N-dimethylamino)- $\alpha, \alpha$-diphenyl olefins 11 with yields ranging from $50 \%$ to $68 \%$; (iv) a nucleophilic displacement of iodide from iodomethane, chloroiodomethane or diiodomethane by the $\omega$-(N,N-dimethylamino)- $\alpha, \alpha$-diphenyl olefins $\mathbf{1 1}$ to obtain the target quaternary ammonium salts (series I and II) with yields between $61 \%$ and $85 \%$. Choline $4 \mathbf{c}$ and choline analogues $4 \mathbf{a}$ and $4 \mathbf{b}$ were prepared as shown in Scheme 2, following the method previously reported [20]. The halomethylated cholines iodides $4 \mathbf{a}$ and $\mathbf{4 b}$ were synthesized from $\mathrm{N}, \mathrm{N}$-dimethyl-2-hydroxyethanamine (12), which was treated with 1.5 equivalents of the corresponding dihalomethane.

\subsection{In Vitro Cytotoxicity of Quaternary N-(Halomethylated) Ammonium Salts 1 and 2, Non N-(Halomethylated) Ammonium Salts 3 and Halogenated Cholines 4}

Compounds were tested first for toxicity on U937 human macrophages at four serial dilution concentrations $\left(200,50,12.5\right.$ and $3.25 \mu \mathrm{g} / \mathrm{mL}$ ) and their $\mathrm{LC}_{50}$ values were determined (Table 1). Choline 4c was also tested as a reference compound. Based on our own classification all of the compounds showed $\mathrm{LC}_{50}<100 \mu \mathrm{g} / \mathrm{mL}$ and were therefore classified as highly cytotoxic, with $2 \mathrm{a}$ being the most cytotoxic $\left(\mathrm{LC}_{50}=46 \mu \mathrm{g} / \mathrm{mL}\right)$. As expected, choline $4 \mathrm{c}$ showed a very low level of cytotoxicity, with $\mathrm{LC}_{50}=372 \mu \mathrm{g} / \mathrm{mL}$. AmB showed high cytotoxicity, while MA was potentially non-cytotoxic to U-937 cells.

Antileishmanial activity of quaternary $\mathrm{N}$-(halomethylated) ammonium salts $\mathbf{1}$ and 2, non- $N$-(halomethylated) ammonium salts $\mathbf{3}$ and halogenated cholines $\mathbf{4 a}$ and $\mathbf{4 b}$ was assessed in both intracellular (inside mammalian U-937 cells) and axenic amastigotes of $L$. $(V)$ panamensis and compared to the activity of choline 4c. All compounds showed antileishmanial activity against both amastigotes (intracellular and axenic) of L. (V) panamensis with $\mathrm{EC}_{50}$ values $<50 \mu \mathrm{g} / \mathrm{mL}$, except $\mathbf{1 b}$ that exhibited an $\mathrm{EC}_{50}=56.3 \mu \mathrm{g} / \mathrm{mL}$ in axenic amastigotes (Table 1). Compound $\mathbf{2 c}$ showed the highest activity with $\mathrm{EC}_{50}$ values of $17.6 \mu \mathrm{g} / \mathrm{mL}$ and $14.0 \mu \mathrm{g} / \mathrm{mL}$ in intracellular and axenic amastigotes, respectively. Compounds $\mathbf{2 b}, \mathbf{3 b}$ and $\mathbf{4 b}$ were also active against both types of amastigotes with $\mathrm{EC}_{50}$ values of $24.0 \mu \mathrm{g} / \mathrm{mL}, 24.7 \mu \mathrm{g} / \mathrm{mL}$ and $23.9 \mu \mathrm{g} / \mathrm{mL}$, respectively (in intracellular amastigotes) and $19.7 \mu \mathrm{g} / \mathrm{mL}$, $25.0 \mu \mathrm{g} / \mathrm{mL}$ and $19.6 \mu \mathrm{g} / \mathrm{mL}$, respectively (in axenic amastigotes) (Table 1). Activity of compounds $3 \mathbf{a}$ and $4 \mathbf{a}$ was high in axenic amastigotes ( $\mathrm{EC}_{50} 25.0$ and $24.3 \mu \mathrm{g} / \mathrm{mL}$, respectively) but moderate in intracellular amastigotes $\left(\mathrm{EC}_{50} 30.0\right.$ and $29.6 \mu \mathrm{g} / \mathrm{mL}$, respectively). The remaining compounds $\mathbf{1 a}-\mathbf{c}$, 2a and $3 \mathbf{c}$ showed moderate activity with $\mathrm{EC}_{50}$ values varying from $27.8 \mu \mathrm{g} / \mathrm{mL}$ to $49.4 \mu \mathrm{g} / \mathrm{mL}$ in intracellular amastigotes and from $34.1 \mu \mathrm{g} / \mathrm{mL}$ to $40.5 \mu \mathrm{g} / \mathrm{mL}$ in axenic amastigotes. As expected, 
compound $4 \mathrm{c}$ (choline) showed almost no activity against intracellular parasites $\left(\mathrm{EC}_{50}=149.5 \mu \mathrm{g} / \mathrm{mL}\right)$ and moderate activity against axenic amastigotes $\left(\mathrm{EC}_{50}<50 \mu \mathrm{g} / \mathrm{mL}\right)$. AmB, one of the used antileishmanial drug, was active against both amastigote types with $\mathrm{EC}_{50}$ values $<1.0 \mu \mathrm{g} / \mathrm{mL}$ while MA was active only against intracellular amastigotes $\left(\mathrm{EC}_{50}=6.33 \mu \mathrm{g} / \mathrm{mL}\right)$ and was not active against axenic parasites (Table 1).

Table 1. Cytotoxicity against U-937 cells and antileishmanial activity of $N$-(halomethylated) ammonium salts, non $N$-(halomethylated) ammonium salts and choline and halogenated cholines.

\begin{tabular}{cccccc}
\hline \multirow{2}{*}{ Compound } & Cytotoxicity & \multicolumn{2}{c}{ Intracellular Amastigotes } & \multicolumn{2}{c}{ Axenic Amastigotes } \\
\cline { 2 - 6 } & LC $_{\mathbf{5 0}}$ & EC $_{\mathbf{5 0}}$ & SI & EC $_{\mathbf{5 0}}$ & SI \\
\hline $\mathbf{1 a}$ & $44.4 \pm 4.9$ & $38.4 \pm 0.2$ & 1.2 & $35.0 \pm 5.7$ & 1.3 \\
$\mathbf{1 b}$ & $21.0 \pm 2.0$ & $46.8 \pm 1.2$ & 0.5 & $56.3 \pm 3.7$ & 0.4 \\
$\mathbf{1 c}$ & $21.0 \pm 0.5$ & $49.4 \pm 3.1$ & 0.4 & $40.5 \pm 3.3$ & 0.5 \\
$\mathbf{2 a}$ & $46.0 \pm 5.4$ & $27.8 \pm 3.9$ & 1.7 & $36.2 \pm 0.1$ & 1.3 \\
$\mathbf{2 b}$ & $10.1 \pm 0.2$ & $\mathbf{2 4 . 0} \pm \mathbf{0 . 7}$ & 0.4 & $\mathbf{1 9 . 7} \pm \mathbf{1 . 5}$ & 0.5 \\
$\mathbf{2 c}$ & $9.5 \pm 0.3$ & $\mathbf{1 7 . 6} \pm \mathbf{1 . 0}$ & 0.5 & $\mathbf{1 4 . 0} \pm \mathbf{0 . 9}$ & 0.7 \\
$\mathbf{3 a}$ & $39.2 \pm 4.8$ & $30.0 \pm 1.4$ & 1.3 & $\mathbf{2 5 . 0} \mathbf{0 . 7}$ & 1.5 \\
$\mathbf{3 b}$ & $27.2 \pm 0.7$ & $\mathbf{2 4 . 7} \pm \mathbf{1 . 9}$ & 1.2 & $\mathbf{2 5 . 0} \pm \mathbf{0 . 5}$ & 1.1 \\
$\mathbf{3 c}$ & $12.5 \pm 0.8$ & $41.6 \pm 2.8$ & 0.3 & $34.1 \pm 5.1$ & 0.4 \\
$\mathbf{4 a}$ & $17.9 \pm 0.02$ & $29.6 \pm 2.8$ & 0.6 & $\mathbf{2 4 . 3} \pm \mathbf{1 . 3}$ & 0.7 \\
$\mathbf{4 b}$ & $17.8 \pm 0.2$ & $\mathbf{2 3 . 9} \pm \mathbf{1 . 0}$ & 0.7 & $\mathbf{1 9 . 6} \pm \mathbf{1 . 8}$ & 0.9 \\
$\mathbf{4 c}$ & $372.0 \pm 43.1$ & $149.5 \pm 17.9$ & 2.5 & $47.2 \pm 7.1$ & 7.9 \\
$\mathrm{AmB}$ & $28.2 \pm 0.5$ & $\mathbf{0 . 0 5} \pm \mathbf{0 . 0 0 1}$ & 560 & $0.041 \pm 0.001$ & 690 \\
$\mathrm{MA}$ & $358.2 \pm 1.7$ & $\mathbf{6 . 3 3} \pm \mathbf{0 . 8 6}$ & 56.6 & $312.1 \pm 18.6$ & 1.4 \\
\hline
\end{tabular}

Results reported as the mean value \pm standard deviation of the half-maximum concentration in $\mu \mathrm{g} / \mathrm{mL}$. AmB: Amphotericin B; MA: meglumine antimoniate; the Selectivity Index $(\mathrm{SI})=\mathrm{LC}_{50} / \mathrm{EC}_{50}$. Bold data represent compounds with high activity against amastigotes of $L$. $(V)$ panamensis.

\section{Discussion}

Based on the facts that: (i) choline is important to the biosynthesis of phosphatidylcholine in Leishmania parasites [15]; (ii) some quaternary ammonium salts such as edelfosine, ilmofosine and miltefosine have antileishmanial activity [17] and; (iii) some quaternary ammonium compounds may efficiently inhibit choline transport in other intracellular parasites such as P. falciparum [19], this work reports the synthesis of a series of new quaternary ammonium salts and their in vitro effectiveness against the human pathogen Leishmania (V.) panamensis, which causes cutaneous and mucocutaneous leishmaniasis.

As shown in Table 1, chlorinated compounds of the series I characterized by the general structure $\left[\mathrm{ClCH}_{2} \mathrm{~N}\left(\mathrm{CH}_{3}\right)_{3}\left(\mathrm{CH}_{2}\right) \mathrm{nCH}=\mathrm{C}(\mathrm{Ph})_{2}\right]^{+} \mathrm{I}^{-}$with $n=2,3$ and $4(\mathbf{1 a}, \mathbf{1 b}$, and $\mathbf{1 c}$, respectively) showed moderate to low activity against axenic amastigotes of $L$. $(V)$ panamensis, with $\mathrm{EC}_{50}$ values ranging between 35 and $57 \mu \mathrm{g} / \mathrm{mL}$, and moderate activity against intracellular amastigotes with $\mathrm{EC}_{50}$ values between 38 and $50 \mu \mathrm{g} / \mathrm{mL}$. These compounds also exhibited high cytotoxicity in U-937 cells with $\mathrm{LC}_{50}$ values ranging from 21 to $45 \mu \mathrm{g} / \mathrm{mL}$. Compound $\mathbf{1 a}(n=2)$ was the most active against axenic amastigotes while $\mathbf{1} \mathbf{b}(n=3)$ was less active than $\mathbf{1 c}(n=4)$. Similarly, $\mathbf{1 a}(n=2)$ exhibits the best activity against intracellular amastigotes while $\mathbf{1 c}(n=4)$ is the worst. In contrast, $1 \mathbf{a}(n=2)$ exhibited the lowest cytotoxicity, while $\mathbf{1 b}(n=3)$ and $\mathbf{1} \mathbf{c}(n=4)$ exhibit similar toxicity.

The selectivity index (SI) is the ratio of the toxicity and activity of a compound, thus it provides a measurement of the balancing effect of these opposing effects. Large values of SI indicate that a compound is relatively active and presents a low toxicity. SI values ranging from 0.4 to 1.3 were found for these three compounds related to their activity against axenic amastigotes. Similar SI values were found in relation to their activity against intracellular amastigotes. In both cases, 1a $(n=2)$ has the best SI. A comparison of compounds $\mathbf{1 a}, \mathbf{1} \mathbf{b}$ and $\mathbf{1} \mathbf{c}$ with respect to chlorocholine $\mathbf{4 a}$ (from series III), reveals that $\mathbf{4 a}$ is more effective against both axenic and intracellular amastigotes 
(EC ${ }_{50}$ decreases), but the toxicity of $4 \mathbf{a}\left(\mathrm{LC}_{50}=17.9 \mu \mathrm{g} / \mathrm{mL}\right)$ is more than two times larger than that for $1 \mathrm{a}\left(\mathrm{LC}_{50}=44.4 \mu \mathrm{g} / \mathrm{mL}\right)$. The results imply that the terminal diphenylethylene moiety in the tail of the $N$-chlorometyl- $N, N$-dimethyl quaternary salts moderates both toxicity and activity with respect to chlorocholine 4 a. Thus, when taking both activity and toxicity into account, compound 1a $(n=2)$ is the $N$-chloromethyl quaternary salt that exhibits the best anti-leishmanial profile in this study. An interesting trend observed for these chlorinated salts is that, upon lengthening the chain, the activity against both axenic amastigotes and intracellular amastigotes decreases but the toxicity steadily increases.

The iodinated compounds 2 of the series $\mathrm{I}$ are salts with the structure $\left[\mathrm{ICH}_{2} \mathrm{~N}\left(\mathrm{CH}_{3}\right)_{3}\left(\mathrm{CH}_{2}\right) \mathrm{nCH}=\mathrm{C}(\mathrm{Ph})_{2}\right]^{+} \mathrm{I}^{-}$with $n=2,3$ and $4(\mathbf{2 a}, \mathbf{2 b}$ and $\mathbf{2 c}$ respectively) exhibit high to moderate activity against axenic amastigotes, with $\mathrm{EC}_{50}$ values varying between 14.0 and $36.0 \mu \mathrm{g} / \mathrm{mL}$ and high activity against intracellular amastigotes with $\mathrm{EC}_{50}$ values ranging between 17.0 and $28.0 \mu \mathrm{g} / \mathrm{mL}$. Contrary to the chlorinated analog salts 1 , the most active $N$-iodomethyl quaternary salt of series I turned out to be the one with the longest aliphatic chain between the quaternary ammonium head and the diphenyl tail, $2 \mathrm{c}(n=4)$, with an $\mathrm{EC}_{50}$ value of $14.0 \mu \mathrm{g} / \mathrm{mL}$ against axenic amastigotes and $17.6 \mu \mathrm{g} / \mathrm{mL}$ against intracellular amastigotes. Also, these iodinated salts were found to have high toxicity with $\mathrm{LC}_{50}$ values ranging between 9 and $46 \mu \mathrm{g} / \mathrm{mL}$. Interestingly, a comparative analysis of $N$-chloromethyl and $N$-iodomethyl quaternary salts implies that the chlorine atom exerts an opposite effect with respect to the iodine atom on the activity against both axenic and intracellular amastigotes but a parallel effect on the toxicity in terms of the effect of the length of the tether chain. However, the effect of lengthening the chain on toxicity is more sensitive when an iodine atom rather than a chlorine atom is present in the cationic ammonium head. For instance, upon lengthering the chain from $n=2$ to $n=4$, the $\mathrm{LC}_{50}$ value goes from $46 \mu \mathrm{g} / \mathrm{mL}$ for $\mathbf{2 a}(n=2)$ to $10.1 \mu \mathrm{g} / \mathrm{mL}$ for $\mathbf{2 b}$ $(n=3)$ and $9.5 \mu \mathrm{g} / \mathrm{mL}$ for $2 \mathrm{c}(n=4)$. In general, iodomethylated salts were both more active against Leishmania parasite and toxic to cells. In terms of the balance between toxicity and antileishmanial activity, the SI of the $N$-iodomethyl quaternary salts of series I (2a, 2b b and $\mathbf{2} \mathbf{c})$ varies from 0.5 to 1.3 for axenic amastigotes and from 0.4 to 1.7 for intracellular amastigotes, with the higher values corresponding to $\mathbf{2 a}(n=2)$. So, $\mathbf{2 a}(n=2)$ would be the most appropriate if we were to choose a lead compound on the basis of its SI value only.

$N$-(2-Hydroxyethyl)- $N$-iodomethyl- $N, N$-dimethylammonium iodide (4b) of series III (iodocholine for short) was also tested. The $\mathrm{EC}_{50}$ for iodocholine $4 \mathrm{~b}$ is similar to that determined for $\mathbf{2 b}(n=3)$ against both axenic and intracellular amastigotes. However, $4 \mathbf{b}$ is a slightly less toxic than $2 \mathbf{b}$ and 2c $\left(\mathrm{LC}_{50}=17.8 \mu \mathrm{g} / \mathrm{mL}\right.$ for $\mathbf{4 b}, 10.1 \mu \mathrm{g} / \mathrm{mL}$ for $\mathbf{2 b}$ and $9.5 \mu \mathrm{g} / \mathrm{mL}$ for $\left.2 \mathrm{c}\right)$, and more toxic than $\mathbf{2 a}$ $\left(\mathrm{LC}_{50}=46 \mu \mathrm{g} / \mathrm{mL}\right)$.

Although in general the iodomethylated salts of the series I behave similar to iodocholine $4 \mathbf{b}$, we can observe higher bioactivity of the $N$-iodomethyl quaternary salt bearing a diphenylethylene unit in the tail and a carbon tether of $n=4$ (i.e., 2c).

Compounds of the series II, characterized by the general structure $\left[\mathrm{CH}_{3} \mathrm{~N}\left(\mathrm{CH}_{3}\right)_{2}\left(\mathrm{CH}_{2}\right) \mathrm{nCH}=\mathrm{C}(\mathrm{Ph})_{2}\right]^{+} \mathrm{I}^{-}$ with $n=2,3$ and 4 (3a, $3 \mathbf{b}$ and $3 \mathbf{c}$ respectively) exhibit high toxicity with the lowest being for $3 \mathbf{a}(n=2$, $\left.\mathrm{LC}_{50}=39.2 \mu \mathrm{g} / \mathrm{mL}\right)$ while increasing when going to $n=3$ and $n=4$, with $3 \mathrm{c}(n=4)$ being the most toxic. These compounds exhibited moderate activity against both axenic and intracellular amastigotes, and it seems that the activity is sensitive to the length of the tether chain in going from $n=3$ to $n=4$.

The results clearly indicate that halogen atoms and the length of the tether chain modify the biological profile of the quaternary salts. In general, the toxicity increases upon lengthening the chain for a particular $\mathrm{X}=\mathrm{H}$ (series II), $\mathrm{Cl}$ or I (Series I). Interestingly, for both $\mathrm{X}=\mathrm{Cl}$ and $\mathrm{I}$, the toxicity largely decreases with the addition of a methylene unit in the tethering chain from $n=2$ to $n=3$ but remains approximately the same with the increase of an additional methylene unit to $n=4$. As previously mentioned, there is a larger decrease when $X=I$ as $L_{50}$ decreases four-fold, while when $X=C l$ the $\mathrm{LC}_{50}$ is halved. In slight contrast, when $\mathrm{X}=\mathrm{H}$ the toxicity seems to step-up as an additional methylene unit is added to the tethering chain $\left(\mathrm{LC}_{50}\right.$ decreases about $12-14 \mu \mathrm{g} / \mathrm{mL}$ per additional methylene 
unit). The changes in the antileishmanial activity are less clear although trends can be discerned as previously noted.

We hypothesize that the molecular structure of the salt (i.e., diphenylethylene moiety and its proximity to the ammonium head) as well as the presence and identity of the halogen in the ammonium head influence the activity and toxicity of $N$-halomethylated quaternary salts. Further knowledge of the interactions between the compounds and proteins or enzymes of the parasite will be key to understanding the relationship between structure and the differential cytotoxicity and anti-leishmanial activity. Indeed, the conformational structure of each compound constitutes a piece of information in the overall picture of the biological behavior of these salts. For that purpose, a recent X-ray diffraction study of the solid state structures of the iodinated compounds of the series I ( $\mathbf{2} \mathbf{a}, \mathbf{2} \mathbf{b}$ and $\mathbf{2} \mathbf{c})$ was carried out [20]. Interestingly, the solid state conformation of $\mathbf{2 a}(n=2)$ differs from that of the $\mathbf{2} \mathbf{b}(n=3)$ and 2c $(n=4)$. The study revealed that conformations may be influenced by supramolecular interactions as well as intramolecular interactions. The understanding of these interactions will be important in both establishing mechanisms of bioavailability of the compounds as they go from the solid state to a liquid/solution phase and on how the most stable conformation of the compounds interact with enzymes or proteins of the parasite. A patent has been granted for compounds 1a, 1c, 2a and 2c [21]. This patent is one of the at least 10 patents that have been granted during the last 10 years to various cores and their derivatives that have been reported to possess antileishmanial activity [22].

\section{Materials and Methods}

\subsection{Structural Characterization}

Structural characterization of compounds was carried out by ${ }^{1} \mathrm{H}-\mathrm{NMR},{ }^{13} \mathrm{C}-\mathrm{NMR}$, elemental analysis and mass spectrometry. ${ }^{1} \mathrm{H}-\mathrm{NMR}$ and ${ }^{13} \mathrm{C}-\mathrm{NMR}$ spectra were obtained at $300 \mathrm{MHz}, 400,500$ and $126 \mathrm{MHz}$ and $75 \mathrm{MHz}$ respectively on a VXR-300, a Gemini-300 both Varian Medical System (Palo Alto, CA, USA) or a Bruker (Billerica, MA, USA) $500 \mathrm{MHz}$ spectrometer. Elemental analyses of carbon, hydrogen and nitrogen were performed at the microanalysis laboratory at the University of Illinois (Urbana-Champaign, IL, USA). Mass spectra were obtained on a HP Series 1100 MSD ESI-MS (Hewlett Packard, Palo Alto, CA, USA) electrospray ionization/mass spectrometer,) using a solution of $0.1 \%$ formic acid in acetonitrile as solvent injection. Samples were dissolved in acetonitrile $(4 \mathrm{mg} / \mathrm{mL})$ prior to injection into the instrument. Melting points were determined on a capillary Thomas-Hoover melting point apparatus (Swedesboro, NJ, USA).

\subsection{Synthesis}

\subsubsection{General Procedure for the Preparation of $\omega$-Bromo- $\alpha, \alpha$-diphenyl Alcohols 9}

The methodology used was according to Horner et al. [23]. All glassware was flame-dried under an inert atmosphere, and reactions were carried out under argon or dry nitrogen. A commercially available ethereal 3M solution of phenylmagnesium bromide (an appropriate volume for 2.6 equivalents) was poured into a three-necked, round-bottomed flask that was equipped with an addition funnel and a vertical condenser. The solution was cooled with an ice-salt bath and then an ethereal solution of the respective $\omega$-bromoacyl chloride 8 ( 1 equivalent) was slowly added from the addition funnel with continuous magnetic stirring while the reaction mixture was kept at about $0{ }^{\circ} \mathrm{C}$. Once the addition was finished, the reactant mixture was kept at $0^{\circ} \mathrm{C}$ during $15 \mathrm{~min}$ and then allowed to slowly reach room temperature. After that, a saturated aqueous $\mathrm{NH}_{4} \mathrm{Cl}$ solution was carefully added and the whole mixture was transferred to a separatory funnel. The organic layer was separated, washed with saturated aqueous $\mathrm{NaCl}$ solution and dried with anhydrous $\mathrm{MgSO}_{4}$. After filtration, solvent was removed by rotary evaporation under reduced pressure. The products were purified by flash column chromatography (hexane:ethyl acetate 5:1 as eluent). White solids or yellow oils were usually obtained. 
4-Bromo-1,1-diphenylbutanol (9a). Starting from 4-bromobutanoyl chloride 8a (5.4 mmol), 9a was obtained as a yellow oil (78\% yield). ${ }^{1} \mathrm{H}-\mathrm{NMR}\left(\mathrm{CDCl}_{3}, 300 \mathrm{MHz}\right) \delta 1.80-1.90(\mathrm{~m}, 2 \mathrm{H}), 2.54-2.94$ $(\mathrm{m}, 2 \mathrm{H}), 3.33(\mathrm{t}, J=6.9 \mathrm{~Hz}, 2 \mathrm{H}), 7.01-7.41(\mathrm{~m}, 10 \mathrm{H}) \mathrm{ppm} .{ }^{13} \mathrm{C}-\mathrm{NMR}\left(\mathrm{CDCl}_{3}, 75 \mathrm{MHz}\right) \delta 22.92,30.91$, $36.18,75.34,123.10-142.24$ ppm.

5-Bromo-1,1-diphenylpentanol (9b). Starting from 5-bromopentanoyl chloride $8 \mathbf{b}(5.0 \mathrm{mmol}), \mathbf{9 b}$ was obtained as a white solid (68\% yield). ${ }^{1} \mathrm{H}-\mathrm{NMR}\left(\mathrm{CDCl}_{3}, 300 \mathrm{MHz}\right) \delta 1.53-1.63(\mathrm{~m}, 2 \mathrm{H}), 2.02-2.12$ $(\mathrm{m}, 2 \mathrm{H}), 2.31-2.41(\mathrm{~m}, 2 \mathrm{H}), 3.47(\mathrm{t}, \mathrm{J}=6.9 \mathrm{~Hz}, 2 \mathrm{H}), 7.23-7.63(\mathrm{~m}, 10 \mathrm{H}) \mathrm{ppm} .{ }^{13} \mathrm{C}-\mathrm{NMR}\left(\mathrm{CDCl}_{3}, 75 \mathrm{MHz}\right)$ $\delta 23.12,28.97,33.62,33.97,41.51,126.53-143.53 \mathrm{ppm}$.

6-Bromo-1,1-diphenylhexanol (9c). Starting from 6-bromohexanoyl chloride 8c (11.7 mmol), 9c was obtained as a yellow oil (72\% yield). ${ }^{1} \mathrm{H}-\mathrm{NMR}\left(\mathrm{CDCl}_{3}, 300 \mathrm{MHz}\right) \delta 1.47-1.57(\mathrm{~m}, 2 \mathrm{H}), 1.91-2.01(\mathrm{~m}, 2 \mathrm{H})$, 2.03-2.13 (m, 2H), 2.27-2.37 (m, 2H), 3.39-3.49 (m, 2H), 7.17-7.57 (m, 10H) ppm. ${ }^{13} \mathrm{C}-\mathrm{NMR}\left(\mathrm{CDCl}_{3}\right.$, $75 \mathrm{MHz}) \delta 23.07,28.90,33.53,33.56,33.87,41.46,126.45-143.48 \mathrm{ppm}$.

\subsubsection{General Procedure for the Preparation of $\omega$-Bromo- $\alpha, \alpha$-diphenyl Olefins 10}

The methodology was according to Horner et al. [18]. A round-bottomed flask was equipped with a Dean-Stark trap and a vertical condenser. Alcohols $\mathbf{9}(\mathbf{a}, \mathbf{b}$ or $\mathbf{c})$ and $p$-toluenesulfonic acid monohydrate $\left(p-\mathrm{TsOH} \cdot \mathrm{H}_{2} \mathrm{O}\right)$ in a molar ratio of about 60:1 were dissolved in benzene and refluxed during $6 \mathrm{~h}$. The approximate concentration of the solution was $5 \mathrm{M}$. After cooling down, the crude mixture was washed with a saturated $\mathrm{NaHCO}_{3}$ aqueous solution and then with a saturated $\mathrm{NaCl}$ solution. The organic layer was dried with anhydrous $\mathrm{MgSO}_{4}$ and filtered, and the solvent was removed by rotary evaporation under reduced pressure. The products were purified by flash column chromatography using hexane as eluent.

4-Bromo-1,1-diphenyl-1-butene (10a). Starting from 9a $(3.9 \mathrm{mmol}), \mathbf{1 0 a}$ was obtained as a yellow oil (90\% yield). ${ }^{1} \mathrm{H}-\mathrm{NMR}\left(\mathrm{CDCl}_{3}, 300 \mathrm{MHz}\right) \delta 2.54-2.64(\mathrm{~m}, 2 \mathrm{H}), 3.32(\mathrm{t}, J=6.9 \mathrm{~Hz}, 2 \mathrm{H}), 5.99(\mathrm{t}, J=7.2 \mathrm{~Hz}$, $1 \mathrm{H}), 7.04-7.34(\mathrm{~m}, 10 \mathrm{H}) \mathrm{ppm} .{ }^{13} \mathrm{C}-\mathrm{NMR}\left(\mathrm{CDCl}_{3}, 75 \mathrm{MHz}\right) \delta 30.57,30.82,123.60-142.20 \mathrm{ppm}$.

5-Bromo-1,1-diphenyl-l-pentene (10b). Starting from $\mathbf{9 b}(3.1 \mathrm{mmol}), \mathbf{1 0 b}$ was obtained as a yellow oil (82\% yield). ${ }^{1} \mathrm{H}-\mathrm{NMR}\left(\mathrm{CDCl}_{3}, 300 \mathrm{MHz}\right) \delta 1.81-1.97(\mathrm{~m}, 2 \mathrm{H}), 2.08-2.22(\mathrm{~m}, 2 \mathrm{H}), 3.27(\mathrm{t}, \mathrm{J}=6.9 \mathrm{~Hz}$, 2H), $5.94(\mathrm{t}, J=7.5 \mathrm{~Hz}, 1 \mathrm{H}), 7.01-7.31(\mathrm{~m}, 10 \mathrm{H}) \mathrm{ppm} .{ }^{13} \mathrm{C}-\mathrm{NMR}\left(\mathrm{CDCl}_{3}, 75 \mathrm{MHz}\right) \delta 26.35,30.97,31.23$, 124.97-141.23 ppm.

6-Bromo-1,1-diphenyl-l-hexene (10c). Starting from 9c $(8.2 \mathrm{mmol}), 10 \mathrm{c}$ was obtained as a yellow oil (84\% yield). ${ }^{1} \mathrm{H}-\mathrm{NMR}\left(\mathrm{CDCl}_{3}, 300 \mathrm{MHz}\right) \delta 1.66-1.74(\mathrm{~m}, 2 \mathrm{H}), 1.91-2.01(\mathrm{~m}, 2 \mathrm{H}), 2.26(\mathrm{c}, J=7.4 \mathrm{~Hz}, 2 \mathrm{H})$, $3.47(\mathrm{t}, J=6.9 \mathrm{~Hz}, 2 \mathrm{H}), 6.18(\mathrm{t}, J=7.4 \mathrm{~Hz}, 1 \mathrm{H}), 7.24-7.54(\mathrm{~m}, 10 \mathrm{H}) \mathrm{ppm} .{ }^{13} \mathrm{C}-\mathrm{NMR}\left(\mathrm{CDCl}_{3}, 75 \mathrm{MHz}\right) \delta$ $28.85,29.26,32.75,34.12,127.42-143.05$ ppm.

\subsubsection{General Procedure for the Preparation of $\omega$-(N,N-Dimethylamino)- $\alpha, \alpha$-diphenyl Olefins 11}

The synthesis of $\omega$-(N,N-dimethylamino)- $\alpha, \alpha$-diphenyl olefins 11 was carried out according to the methodology reported by Ríos et al. [24]. The reaction of $\omega$-bromo- $\alpha$, $\alpha$-diphenyl olefins $\mathbf{1 0}$ with a $40 \%$ aqueous dimethylamine solution was carried out using the appropriate volume for a molar ratio 26:1 of amine to olefin 10. The aqueous dimethylamine solution was poured into a round-bottomed flask, and then a tetrahydrofuran (THF) solution of $\mathbf{1 0}(\mathbf{a}, \mathbf{b}$ or $\mathbf{c})$ was slowly added to the amine solution. The mixture was stirred at room temperature overnight and then it was transferred to a separatory funnel and extracted with diethyl ether. The organic layer was separated and extracted with aqueous $10 \% \mathrm{HCl}$. The aqueous extract was neutralized with aqueous $10 \% \mathrm{NaOH}$ and it was extracted again with diethyl ether. The ether extract was dried with anhydrous $\mathrm{MgSO}_{4}$ and filtered. The solvent was removed by rotary evaporation under reduced pressure, yielding the expected amines as yellow oils.

N,N-Dimethyl-4,4-diphenyl-3-butenylamine (11a). Starting from 10a (3.1 mmol), 11a was obtained as yellow oil (50\% yield). ${ }^{1} \mathrm{H}-\mathrm{NMR}\left(\mathrm{CDCl}_{3}, 300 \mathrm{MHz}\right) \delta 2.07(\mathrm{~s}, 6 \mathrm{H}), 2.12-2.22(\mathrm{~m}, 2 \mathrm{H}), 2.23-2.33$ 
$(\mathrm{m}, 2 \mathrm{H}), 5.97(\mathrm{t}, J=7.3 \mathrm{~Hz}, 1 \mathrm{H}), 7.00-7.30(\mathrm{~m}, 10 \mathrm{H}) \mathrm{ppm} .{ }^{13} \mathrm{C}-\mathrm{NMR}\left(\mathrm{CDCl}_{3}, 75 \mathrm{MHz}\right) \delta 26.14,43.25$, $57.52,124.76-140.43 \mathrm{ppm}$.

$\mathrm{N}, \mathrm{N}$-Dimethyl-5,5-diphenyl-4-pentenylamine (11b). Starting from $\mathbf{1 0 b}(2.2 \mathrm{mmol}), \mathbf{1 1} \mathbf{b}$ was obtained as yellow oil (68\% yield). ${ }^{1} \mathrm{H}-\mathrm{NMR}\left(\mathrm{CDCl}_{3}, 300 \mathrm{MHz}\right) \delta 1.44-1.54(\mathrm{~m}, 2 \mathrm{H}), 2.00-2.10(\mathrm{~m}, 2 \mathrm{H}), 2.14(\mathrm{~s}, 6 \mathrm{H})$, 2.21-2.31 (m, 2H), $5.98(\mathrm{t}, J=7.5 \mathrm{~Hz}, 1 \mathrm{H}), 7.00-7.30(\mathrm{~m}, 10 \mathrm{H}) \mathrm{ppm} .{ }^{13} \mathrm{C}-\mathrm{NMR}\left(\mathrm{CDCl}_{3}, 75 \mathrm{MHz}\right) \delta 25.34$, $26.26,43.23,57.71,124.28-140.60 \mathrm{ppm}$.

$\mathrm{N}, \mathrm{N}$-Dimethyl-6,6-diphenyl-5-hexenylamine (11c). Starting from 10c $(6.5 \mathrm{mmol}), 11 \mathrm{c}$ was obtained as yellow oil (61\% yield). ${ }^{1} \mathrm{H}-\mathrm{NMR}\left(\mathrm{CDCl}_{3}, 300 \mathrm{MHz}\right) \delta 1.25-1.34(\mathrm{~m}, 2 \mathrm{H}), 1.48-1.57,(\mathrm{~m}, 2 \mathrm{H}), 2.18-2.29$ $(\mathrm{m}, 2 \mathrm{H}), 2.20-2.29(\mathrm{~m}, 2 \mathrm{H}), 2.26(\mathrm{~s}, 6 \mathrm{H}), 6.16(\mathrm{t}, J=7.5 \mathrm{~Hz}, 1 \mathrm{H}), 7.20-7.51(\mathrm{~m}, 10 \mathrm{H}) \mathrm{ppm} .{ }^{13} \mathrm{C}-\mathrm{NMR}$ $\left(\mathrm{CDCl}_{3}, 75 \mathrm{MHz}\right) \delta 27.78,28.24,30.06,45.94,60.10,127.21-143.26 \mathrm{ppm}$.

\subsubsection{General Procedure for the Preparation of Quaternary Ammonium Salts 1-3 (Series I and II)}

Synthesis of series I and II of quaternary ammonium salts was according to the methodology reported by Ríos et al. [24]. The reaction of $\omega$-(N,N-dimethylamino)- $\alpha, \alpha$-diphenyl olefins $\mathbf{1 1} \mathbf{a}, \mathbf{b}$ or $\mathbf{c})$ with a $50 \%$ acetonitrile solution of $\mathrm{XCH}_{2} \mathrm{I}$ (with $\mathrm{X}=\mathrm{Cl}$ or I for the series $\mathrm{I}$, and $\mathrm{X}=\mathrm{H}$ for the series II) was carried out using a 4:1 molar ratio of $\mathrm{XCH}_{2} \mathrm{I}$ to amine 11. The starting tertiary amine $\mathbf{1 1}$ and the acetonitrile solution of the respective $\mathrm{XCH}_{2} \mathrm{I}$ substrate were mixed in a round-bottomed flask, and the reactions were allowed to run overnight in the dark. The precipitated salts were filtered off and then washed several times with diethyl ether or ethyl acetate, and then recrystallized from water. The pure quaternary ammonium salts were obtained as white solids.

$\mathrm{N}$-Chloromethyl-N,N-dimethyl-N-(4,4-diphenylbut-3-en-1-yl)ammonium iodide (1a). Starting from 11a and $\mathrm{ClCH}_{2} \mathrm{I}$, salt 1a (85\% yield) was obtained as a white solid, m.p. $140-142{ }^{\circ} \mathrm{C} .{ }^{1} \mathrm{H}-\mathrm{NMR}\left(\mathrm{D}_{2} \mathrm{O}, 300 \mathrm{MHz}\right)$ 反 2.31-2.53 (m, 2H), $3.02(\mathrm{~s}, 6 \mathrm{H}), 3.37-3.55(\mathrm{~m}, 2 \mathrm{H}), 5.11(\mathrm{~s}, 2 \mathrm{H}), 5.99(\mathrm{t}, J=7.3 \mathrm{~Hz}, 1 \mathrm{H}), 7.04-7.47$ $(\mathrm{m}, 10 \mathrm{H})$ ppm. ${ }^{13} \mathrm{C}-\mathrm{NMR}\left(\mathrm{D}_{2} \mathrm{O}, 75 \mathrm{MHz}\right) \delta 23.31,49.42,61.43,68.13,121.97,127.18-129.46,138.76$, $141.46,145.22$ ppm. Elemental analysis: calc. for $\mathrm{C}_{19} \mathrm{H}_{23} \mathrm{NICl}$ : C, $53.35 \% ; \mathrm{H}, 5.42 \%$; N, 3.27\%; found C, $53.35 \% ; \mathrm{H}, 5.34 \%$; N, 3.28\%. MS-ESI $m / z$ calc. for $\left[\mathrm{C}_{19} \mathrm{H}_{23} \mathrm{NCl}\right]^{+}: 300.15 \mathrm{amu}$, found: $300.20 \mathrm{amu}$.

$\mathrm{N}$-Chloromethyl-N,N-dimethyl-N-(5,5-diphenylpent-4-en-1-yl)ammonium iodide (1) $)$. Starting from $\mathbf{1 1} \mathbf{b}$ and $\mathrm{ClCH}_{2} \mathrm{I}$, salt $\mathbf{1 b}$ (84\% yield) was obtained as a white solid, m.p. $121-124{ }^{\circ} \mathrm{C} .{ }^{1} \mathrm{H}-\mathrm{NMR}$ (DMSO, $300 \mathrm{MHz}) \delta 1.83-1.93(\mathrm{~m}, 2 \mathrm{H}), 2.06-2.16(\mathrm{~m}, 2 \mathrm{H}), 3.12(\mathrm{~s}, 6 \mathrm{H}), 3.38-3.45(\mathrm{~m}, 2 \mathrm{H}), 5.33(\mathrm{~s}, 2 \mathrm{H}), 6.12$ $(\mathrm{t}, J=7.2 \mathrm{~Hz}, 1 \mathrm{H}), 7.07-7.53(\mathrm{~m}, 10 \mathrm{H}) \mathrm{ppm} .{ }^{13} \mathrm{C}-\mathrm{NMR}$ (DMSO, $\left.75 \mathrm{MHz}\right) \delta 24.96,29.09,52.01,64.92$, 71.35, 129.93-132.46, 142.13, 144.69, 145.58 ppm. Elemental analysis: calc. for $\mathrm{C}_{20} \mathrm{H}_{25} \mathrm{NICl}$ : C, $54.37 \%$; $\mathrm{H}, 5.70 \%$; N, 3.17\%; found C, $53.39 \% ; \mathrm{H}, 5.57 \% ; \mathrm{N}, 3.17 \%$. MS-ESI $m / z$ calc. for $\left[\mathrm{C}_{20} \mathrm{H}_{25} \mathrm{NCl}\right]^{+}: 314.17$ amu, found: $314.20 \mathrm{amu}$.

$\mathrm{N}$-Chloromethyl-N,N-dimethyl-N-(6,6-diphenylhex-5-en-1-yl)ammonium iodide (1c). Starting from 11c and $\mathrm{ClCH}_{2} \mathrm{I}$, salt 1c (61\% yield) was obtained as a white solid, m.p. $119-121{ }^{\circ} \mathrm{C} .{ }^{1} \mathrm{H}-\mathrm{NMR}\left(\mathrm{CDCl}_{3}, 400 \mathrm{MHz}\right)$ $\delta 1.53-1.63(\mathrm{~m}, 2 \mathrm{H}), 1.70-1.80(\mathrm{~m}, 2 \mathrm{H}), 2.18-2.26(\mathrm{~m}, 2 \mathrm{H}), 3.46(\mathrm{~s}, 6 \mathrm{H}), 3.60-3.68(\mathrm{~m}, 2 \mathrm{H}), 5.64(\mathrm{~s}, 2 \mathrm{H})$, $6.05(\mathrm{t}, J=7.4 \mathrm{~Hz}, 1 \mathrm{H}), 7.12-7.42(\mathrm{~m}, 10 \mathrm{H}) \mathrm{ppm} .{ }^{13} \mathrm{C}-\mathrm{NMR}\left(\mathrm{CDCl}_{3}, 101 \mathrm{MHz}\right) \delta 22.23,26.25,28.91,49.96$, $63.15,68.92,127.16-129.82,139.76,142.25,142.97$ ppm. Elemental analysis: calc. for $\mathrm{C}_{21} \mathrm{H}_{27} \mathrm{NICl}$ : C, $55.34 \% ; \mathrm{H}, 5.97 \%$; N $3.07 \%$; found $\mathrm{C}, 55.10 \% ; \mathrm{H}, 5.95 \%$;, $3.10 \%$. MS-ESI $m / z$ calc. for $\left[\mathrm{C}_{21} \mathrm{H}_{27} \mathrm{NCl}\right]^{+}$: $328.18 \mathrm{amu}$, found: $328.20 \mathrm{amu}$.

$\mathrm{N}$-Iodomethyl-N,N-dimethyl-N-(4,4-diphenylbut-3-en-1-yl)ammonium iodide (2a). Starting from 11a and $\mathrm{CH}_{2} \mathrm{I}_{2}$, salt $2 \mathrm{a}$ (74\% yield) was obtained as a white solid, m.p. $152-154{ }^{\circ} \mathrm{C} .{ }^{1} \mathrm{H}-\mathrm{NMR}$ (DMSO, $300 \mathrm{MHz} \delta$, ppm.): 2.43-2.53 (m, 2H), $3.12(\mathrm{~s}, 6 \mathrm{H}), 3.45-3.55(\mathrm{~m}, 2 \mathrm{H}), 5.05(\mathrm{~s}, 2 \mathrm{H}), 6.07(\mathrm{t}, J=7.4 \mathrm{~Hz}$, $1 \mathrm{H}), 7.15-7.58(\mathrm{~m}, 10 \mathrm{H}) \mathrm{ppm} .{ }^{13} \mathrm{C}-\mathrm{NMR}$ (DMSO, $\left.75 \mathrm{MHz}, \delta, \mathrm{ppm}\right) \delta 23.70,31.49,51.66,63.58,121.92$, 127.19-129.51, 138.79, 141.62, 145.03 ppm. Elemental analysis: calculated for $\mathrm{C}_{19} \mathrm{H}_{23} \mathrm{NI}_{2}: \mathrm{C}, 43.95 \%$; $\mathrm{H}, 4.46 \% ; \mathrm{N}, 2.70 \%$; found, $\mathrm{C}, 43.48 \% ; \mathrm{H}, 4.35 \% ; \mathrm{N}, 2.68 \%$. MS-ESI $m / z$ calculated for cation $\left[\mathrm{C}_{19} \mathrm{H}_{23} \mathrm{NI}\right]^{+}: 392.09 \mathrm{amu}$, found: $391.95 \mathrm{amu}$. 
N-Iodomethyl-N,N-dimethyl-N-(5,5-diphenyl-4-penten-1-yl)ammonium iodide (2b). Starting from $\mathbf{1 1 b}$ and $\mathrm{CH}_{2} \mathrm{I}_{2}$, salt $\mathbf{2 b}\left(77 \%\right.$ yield) was obtained as a white solid, m.p. 157-158 ${ }^{\circ} \mathrm{C} .{ }^{1} \mathrm{H}-\mathrm{NMR}$ (DMSO, $300 \mathrm{MHz} \delta, \mathrm{ppm}): 1.80-1.90$ (m, 2H), 2.07-2.17 (m, 2H), 3.15 (s, 6H), 3.31-3.40 (m, 2H), 5.18 (s, $2 \mathrm{H}), 6.14$ $(\mathrm{t}, J=7.2 \mathrm{~Hz}, 1 \mathrm{H}), 7.11-7.51(10 \mathrm{H}) .{ }^{13} \mathrm{C}-\mathrm{NMR}$ (DMSO, $\left.75 \mathrm{MHz}, \delta, \mathrm{ppm}\right): 22.30,25.91,39.01,51.19,63.84$, 126.84-141.68. ESI-MS $m / z$ calc. for $\left[\mathrm{C}_{20} \mathrm{H}_{25} \mathrm{NI}\right]^{+}: 406.10 \mathrm{amu}$, found: $406.20 \mathrm{amu}$.

N-Iodomethyl-N,N-dimethyl-N-(6,6-diphenylhex-5-en-1-yl)ammonium iodide (2c). Starting from 11c and $\mathrm{CH}_{2} \mathrm{I}_{2}$, salt $2 \mathrm{c}\left(72 \%\right.$ yield) was obtained as a white solid, m.p. $156-158^{\circ} \mathrm{C} .{ }^{1} \mathrm{H}-\mathrm{NMR}$ (DMSO, $300 \mathrm{MHz}$ $\delta, \mathrm{ppm}):$ 1.42-1.46 (m, 2H), 1.64-1.72 (m, 2H), 2.08-2.15 (m, 2H), $3.10(\mathrm{~s}, 6 \mathrm{H}), 3.33-3.44(\mathrm{~m}, 2 \mathrm{H}), 5.14$ $(\mathrm{s}, 2 \mathrm{H}), 6.14(\mathrm{t}, J=7.3 \mathrm{~Hz}, 1 \mathrm{H}), 7.06-7.51(\mathrm{~m}, 10 \mathrm{H}) \mathrm{ppm} .{ }^{13} \mathrm{C}-\mathrm{NMR}$ (DMSO, $\left.75 \mathrm{MHz}, \delta, \mathrm{ppm}\right): 25.07$, 28.91, 31.91, 35.35, 54.29, 67.34, 129.89-132.50, 130.19, 142.45, 144.34, 145.02. Elemental analysis: calc. for $\mathrm{C}_{21} \mathrm{H}_{27} \mathrm{NI}_{2}$ : C, $46.09 \% ; \mathrm{H}, 4.97 \%$; N, 2.56\%; found C, $45.91 \% ; \mathrm{H}, 4.93 \%$; N, 2.58\%. MS-ESI $\mathrm{m} / \mathrm{z}$ calc. for $\left[\mathrm{C}_{21} \mathrm{H}_{27} \mathrm{NI}\right]^{+}: 420.12 \mathrm{amu}$, found: $420.20 \mathrm{amu}$.

N,N,N-Trimethyl-N-(4,4-diphenylbut-3-en-1-yl)ammonium iodide (3a). Starting from 11a and $\mathrm{CH}_{3} \mathrm{I}$, salt 3a (82\% yield) was obtained as a white solid, m.p. 190-192 ${ }^{\circ} \mathrm{C} .{ }^{1} \mathrm{H}-\mathrm{NMR}$ (DMSO, $\left.300 \mathrm{MHz}\right) \delta 2.54-2.63$ $(\mathrm{m}, 2 \mathrm{H}), 3.11(\mathrm{~s}, 9 \mathrm{H}), 3.53-3.63(\mathrm{~m}, 2 \mathrm{H}), 6.13(\mathrm{t}, J=7.1 \mathrm{~Hz}, 1 \mathrm{H}), 7.18-7.66(\mathrm{~m}, 10 \mathrm{H}) \mathrm{ppm} .{ }^{13} \mathrm{C}-\mathrm{NMR}$ (DMSO $75 \mathrm{MHz}$ ) $\delta 24.03,52.52,64.92,123.28-144.69$ ppm. Elemental analysis: calc. for $\mathrm{C}_{19} \mathrm{H}_{24} \mathrm{NI}_{\mathrm{C}} \mathrm{C}$, $58.02 \%$; H, 6.15\%; N, 3.56\%; found C, 56.71\%; H, 6.23\%; N, 3.52\%. MS-ESI $m / z$ calc. for $\left[\mathrm{C}_{19} \mathrm{H}_{24} \mathrm{~N}^{+}\right.$: $266.19 \mathrm{amu}$, found: $266.20 \mathrm{amu}$.

$N, N, N-$ Trimethyl-N-(5,5-diphenylpent-4-en-1-yl)ammonium iodide (3b). Starting from $\mathbf{1 1 b}$ and $\mathrm{CH}_{3} \mathrm{I}$, salt $3 \mathbf{b}\left(92 \%\right.$ yield) was obtained as a white solid, m.p. $196-197{ }^{\circ} \mathrm{C} .{ }^{1} \mathrm{H}-\mathrm{NMR}$ (DMSO, $\left.400 \mathrm{MHz}\right) \delta 1.87-1.93$ $(\mathrm{m}, 2 \mathrm{H}), 2.24(\mathrm{c}, J=7.1 \mathrm{~Hz}, 2 \mathrm{H}), 3.37(\mathrm{~s}, 9 \mathrm{H}), 3.43-3.55(\mathrm{~m}, 2 \mathrm{H}), 6.08(\mathrm{t}, J=7.1 \mathrm{~Hz}, 1 \mathrm{H}), 7.10-7.45$ $(\mathrm{m}, 10 \mathrm{H})$ ppm. ${ }^{13} \mathrm{C}-\mathrm{NMR}$ (DMSO, $101 \mathrm{MHz}$ ) $\delta$ 23.41, 26.19, 53.32, 66.67, 125.90, 127.14-128.92, 139.39, 141.82, 143.96 ppm. Elemental analysis: calc. for $\mathrm{C}_{20} \mathrm{H}_{26} \mathrm{NI}$ : C, 58.97\%; H, 6.43\%; N, 3.44\%; found C, $55.93 \%$;, $6.10 \%$; N 3.23\%. MS-ESI $m / z$ calc. for $\left[\mathrm{C}_{20} \mathrm{H}_{26} \mathrm{~N}\right]^{+}: 280.21 \mathrm{amu}$, found: $280.20 \mathrm{amu}$.

N,N,N-Trimethyl-N-(6,6-diphenylhex-5-en-1-yl)ammonium iodide (3c). Starting from 11c and $\mathrm{CH}_{3} \mathrm{I}$, salt 3c (72\% yield) was obtained as a white solid, m.p. 202-204 ${ }^{\circ} \mathrm{C} .{ }^{1} \mathrm{H}-\mathrm{NMR}$ (DMSO, $\left.500 \mathrm{MHz}\right) \delta 1.40-1.46$ $(\mathrm{m}, 2 \mathrm{H}), 1.64-1.72(\mathrm{~m}, 2 \mathrm{H}), 2.11(\mathrm{c}, J=7.4 \mathrm{~Hz}, 2 \mathrm{H}), 3.03(\mathrm{~s}, 9 \mathrm{H}), 3.20-3.30(\mathrm{~m}, 2 \mathrm{H}), 6.16(\mathrm{t}, J=7.4 \mathrm{~Hz}, 1 \mathrm{H})$, 7.10-7.49 (m, 10H) ppm. ${ }^{13} \mathrm{C}-\mathrm{NMR}$ (DMSO, $\left.126 \mathrm{MHz}\right) \delta$ 22.22, 26.22, 29.12, 52.69, 65.82, 127.10-129.12, $129.71,139.78,141.76,142.26$ ppm. Elemental analysis: calc. for $\mathrm{C}_{21} \mathrm{H}_{28} \mathrm{NI}$ : C, 59.86\%; $\mathrm{H}, 6.70 \%$; $\mathrm{N}, 3.32 \%$; found C, $59.49 \%$;, $6.74 \%$; N, 3.35\%. MS-ESI $m / z$ calc. for $\left[\mathrm{C}_{21} \mathrm{H}_{28} \mathrm{~N}\right]^{+}: 294.22$ amu, found: $294.20 \mathrm{amu}$.

4.2.5. General Procedure for the Preparation of Choline $\mathbf{4 c}$ and Choline Analogs $4 \mathbf{a}$ and $\mathbf{4 b}$ (Series III)

The compounds $\mathbf{4 a}, \mathbf{4 b}$ and $\mathbf{4} \mathbf{c}$ were prepared following the procedure reported by Mistry et al. [25] starting from $\mathrm{N}, \mathrm{N}$-dimethylethanolamine 12 and $\mathrm{XCH}_{2} \mathrm{I}$ in $\mathrm{THF}$ (with $\mathrm{X}=\mathrm{H}, \mathrm{Cl}$ or I), using a 1.5:1 molar ratio of $\mathrm{XCH}_{2} \mathrm{I}$ to ethanolamine. The reaction mixture was stirred in the dark for $24 \mathrm{~h}$ at room temperature. The gummy crude product was washed with dry THF, and the resulting salts were filtered off to obtain the products as white solids.

$N$-Choromethyl-N,N-dimethyl-N-(2-hydroxyet-1-yl)ammonium iodide (4a). Starting from N,N-dimethylethanolamine (12) and $\mathrm{ClCH}_{2} \mathrm{I}, 4 \mathbf{a}\left(51.2 \%\right.$ yield) was obtained as a white solid, m.p. $101-103{ }^{\circ} \mathrm{C}$ ${ }^{1} \mathrm{H}-\mathrm{NMR}\left(\mathrm{D}_{2} \mathrm{O}, 300 \mathrm{MHz}\right) \delta 3.32(\mathrm{~s}, 6 \mathrm{H}), 3.62-3.74(\mathrm{~m}, 2 \mathrm{H}), 4.01-4.10(\mathrm{~m}, 2 \mathrm{H}), 5.28(\mathrm{~s}, 2 \mathrm{H}) \mathrm{ppm}$. ${ }^{13} \mathrm{C}-\mathrm{NMR}\left(\mathrm{D}_{2} \mathrm{O}, 75 \mathrm{MHz}\right) \delta 33.11,53.14,55.95,66.46$ ppm.

$N$-Iodomethyl-N,N-dimethyl-N-(2-hydroxyet-1-yl)ammonium iodide (4b). Starting from N,N-dimethylethanolamine (12) and $\mathrm{CH}_{2} \mathrm{I}_{2}, 4 \mathbf{b}(61.5 \%$ yield $)$ was obtained as a white solid, m.p. $96-97^{\circ} \mathrm{C} .{ }^{1} \mathrm{H}-\mathrm{NMR}$ $\left(\mathrm{D}_{2} \mathrm{O}, 300 \mathrm{MHz}\right) \delta 3.33(\mathrm{~s}, 6 \mathrm{H}), 3.65-3.74(\mathrm{~m}, 2 \mathrm{H}), 4.01-4.13(\mathrm{~m}, 2 \mathrm{H}), 5.29(\mathrm{~s}, 2 \mathrm{H}) \mathrm{ppm} .{ }^{13} \mathrm{C}-\mathrm{NMR}$ $\left(\mathrm{D}_{2} \mathrm{O}, 75 \mathrm{MHz}\right) \delta 33.32,53.22,56.14,66.51 \mathrm{ppm}$. 
(2-Hydroxyethyl)trimethylammonium iodide (choline) (4c). Starting from $N, N$-dimethylethanolamine (12) and $\mathrm{CH}_{3} \mathrm{I}, 4 \mathrm{c}$ (88\% yield) was obtained as a white solid, m.p. $268-270{ }^{\circ} \mathrm{C} .{ }^{1} \mathrm{H}-\mathrm{NMR}\left(\mathrm{D}_{2} \mathrm{O}, 300 \mathrm{MHz}\right)$, $\delta 3.20(\mathrm{~s}, 9 \mathrm{H}), 3.49-3.55(\mathrm{~m}, 2 \mathrm{H}), 4.00-4.10(\mathrm{~m}, 2 \mathrm{H}) \mathrm{ppm} .{ }^{13} \mathrm{C}-\mathrm{NMR}\left(\mathrm{D}_{2} \mathrm{O} ; 75 \mathrm{MHz}\right) \delta 54.39,55.63$, 67.98 ppm.

The spectral data of the synthesized $\omega$-bromo- $\alpha, \alpha$-diphenyl alcohols $9, \omega$-bromo- $\alpha, \alpha$-diphenyl olefins 10 and $\omega$-(N,N-dimethylamino)- $\alpha, \alpha$-diphenyl olefins $\mathbf{1 1}$ were in agreement with those reported previously by Horner et al. [18]. All compounds were stored at room temperature until use. Prior to the biological testing, each compound was solubilized in 0.5\% dimethyl sulfoxide (DMSO; Sigma-Aldrich, St. Louis, MO, USA), and then diluted to the appropriate concentration in culture media.

\subsection{Biological Activity}

\subsubsection{Cells and Culture Conditions}

U-937 promonocytes (CRL1593.2 ${ }^{\mathrm{TM}}$ ) were obtained from the American Type Culture Collection (ATCC, Manassas, VA, USA), cultured in complete medium containing RPMI 1640 medium (Sigma) supplemented with 10\% fetal bovine serum (FBS) (Gibco, Life Technologies, Grand Island, NY, USA) and $1 \%$ antibiotics $(100 \mathrm{U} / \mathrm{mL}$ penicillin and $0.1 \mathrm{mg} / \mathrm{mL}$ streptomycin) (Sigma). Cells were maintained in standard conditions at $37^{\circ} \mathrm{C}, 5 \% \mathrm{CO}_{2}$ with change of medium every three days until use.

\subsubsection{Leishmania Strain and Cultivation of Parasites}

Virulent L. $(V)$ panamensis MHOM/CO/87/UA140 strain transfected with green fluorescent protein gene called $L$. $(V)$ panamensis-pIR-eGFP was maintained by successive passaging in golden hamsters (Mesocricetus auratus). Briefly, amastigotes were aspirated from cutaneous lesions of hamsters experimentally infected with promastigotes of $L$. $(V)$ panamensis-pIR-eGFP. Samples were cultured in biphasic culture with Novy-MacNeal-Nicholle (NNN) medium as solid phase and PBS plus glucose, pH 6.9 as liquid phase and incubated at $26^{\circ} \mathrm{C}$ to obtain promastigotes. Medium was changed every week until 2 months.

The axenic amastigotes were obtained from promastigotes cutured in Schneider's medium, as described elsewhere [26]. Briefly, promastigotes of L. (V) panamensis-pIR-eGFP at $5 \times 10^{6}$ parasites $/ \mathrm{mL}$ were cultured in Schneider medium (Sigma), pH 5.4 supplemented with 20\% FBS and 1\% antibiotics and incubation at $26^{\circ} \mathrm{C}$. Every three days, medium was changed and temperature was increased one degree each time until it reached $32{ }^{\circ} \mathrm{C}$ at which the transformation of the promastigotes into axenic amastigotes is achieved. After three days of growing as axenic amastigotes, parasites were ready to be used in the antileishmanial testing assay as described below.

Intracellular amastigotes were obtained after infection of U-937 cells with promastigotes. Briefly, U-937 cells were dispensed in 24-well plates at a concentration of 300,000 cells/well and were treated with $1 \mu \mathrm{M}$ of phorbol myristate acetate (PMA) (Sigma) for $48 \mathrm{~h}$ at $37^{\circ} \mathrm{C}$. Then, cells were infected with promastigotes in stationary growth phase (day 5) at a ratio of 1:15 cell/parasite and incubated for $3 \mathrm{~h}$ at $34{ }^{\circ} \mathrm{C}$ in $5 \% \mathrm{CO}_{2}$. Cells were washed twice with PBS to eliminate not internalized parasites and fresh RPMI-1640 was added into each well $(1 \mathrm{~mL})$; plates were incubated again at $34{ }^{\circ} \mathrm{C}$ and $5 \% \mathrm{CO}_{2}$ to allow intracellular differentiation of promastigotes to amastigotes form. After $24 \mathrm{~h}$ of infection, cells were ready to be used in antileishmanial testing assay as described below.

\subsubsection{In Vitro Cytotoxicity Using U-937 Cells}

The cytotoxicity of compounds was assessed based on the viability of U-937 cells and evaluated by the MTT (3-(4,5-dimethylthiazol-2-yl)-2,5-diphenyltetrazolium bromide) method as described by others [26]. Briefly, into each well of a 96-well cell-culture dishes 100,000 cells / $100 \mu \mathrm{L}$ were dispensed in RPMI-1640 supplemented with $10 \%$ FBS and $100 \mu \mathrm{L}$ of the corresponding concentrations of the corresponding product. Six two fold serial dilutions were were tested starting at $200 \mu \mathrm{g} / \mathrm{mL}(200$, $100,50,25,12.5$ and $6.25 \mu \mathrm{g} / \mathrm{mL})$. Cells were incubated at $37^{\circ} \mathrm{C}$ with $5 \% \mathrm{CO}_{2}$ for $72 \mathrm{~h}$ in the presence 
of compounds, and then the effect was determined by measuring the activity of the mitochondrial dehydrogenase by adding $10 \mu \mathrm{L} /$ well of MTT solution $(0.5 \mathrm{mg} / \mathrm{mL})$ and incubating at $37^{\circ} \mathrm{C}$ for $3 \mathrm{~h}$. The reaction was stopped by adding $100 \mu \mathrm{L} /$ well of $50 \%$ isopropanol solution with $10 \%$ sodium dodecyl sulfate for $30 \mathrm{~min}$. Cell growth was determined based on the quantity of formazan produced, which was measured at $570 \mathrm{~nm}$ in a plate reader spectrophotometer (Bio-Rad, Hercules, CA, USA). Cells cultured in the absence of products were used as cell growth controls (negative control), while cells cultured in presence of amphotericin B (AmB, Sigma) and meglumine antimoniate (MA, Sanofi-Aventis, Bogotá, Colombia) were used as cytotoxicity controls (positive control). Each concentration was tested in triplicate in at least two independent experiments.

\subsubsection{In Vitro Leishmanicidal Activity on Intracellular Amastigotes}

The effect of compounds against intracellular amastigotes of $L .(V)$ panamensis-pIR-eGFP was evaluated by flow cytometry using the methodology described by others [27]. After $24 \mathrm{~h}$ of infection of U-937 cells, culture medium was replaced by fresh complete RPMI 1640 medium containing each compound at the corresponding concentration (four serial dilution were prepared starting at a concentration not exceeding the $\mathrm{LC}_{50}$ previously determined). Infected and treated cells were maintained at $34{ }^{\circ} \mathrm{C}$ and $5 \% \mathrm{CO}_{2}$ for $72 \mathrm{~h}$. After $72 \mathrm{~h}$, cells were washed twice with $1 \mathrm{~mL}$ of cold PBS and cells were removed from the bottom plate with a trypsin/EDTA $(250 \mathrm{mg} / \mathrm{mL})$ solution. Recovered cells were centrifuged at $1100 \mathrm{rpm}$ for $10 \mathrm{~min}$ at $4{ }^{\circ} \mathrm{C}$, the supernatant was discarded and cells were washed with $1 \mathrm{~mL}$ of cold PBS and centrifuged at $1100 \mathrm{rpm}$ for $10 \mathrm{~min}$ at $4{ }^{\circ} \mathrm{C}$. Supernatant was discarded and cells were suspended in $500 \mu \mathrm{L}$ of PBS and analyzed by flow cytometry (FC 500MPL, Cytomics, Brea, CA, USA) using histogram analyses (Figure 2). Infected cells treated with AmB or MA were used as control for antileishmanial activity (positive control) while infected cells incubated in culture RPMI 1640 medium alone were used as control for infection (negative control). Each concentration of compounds was tested in triplicate in two independent experiments.

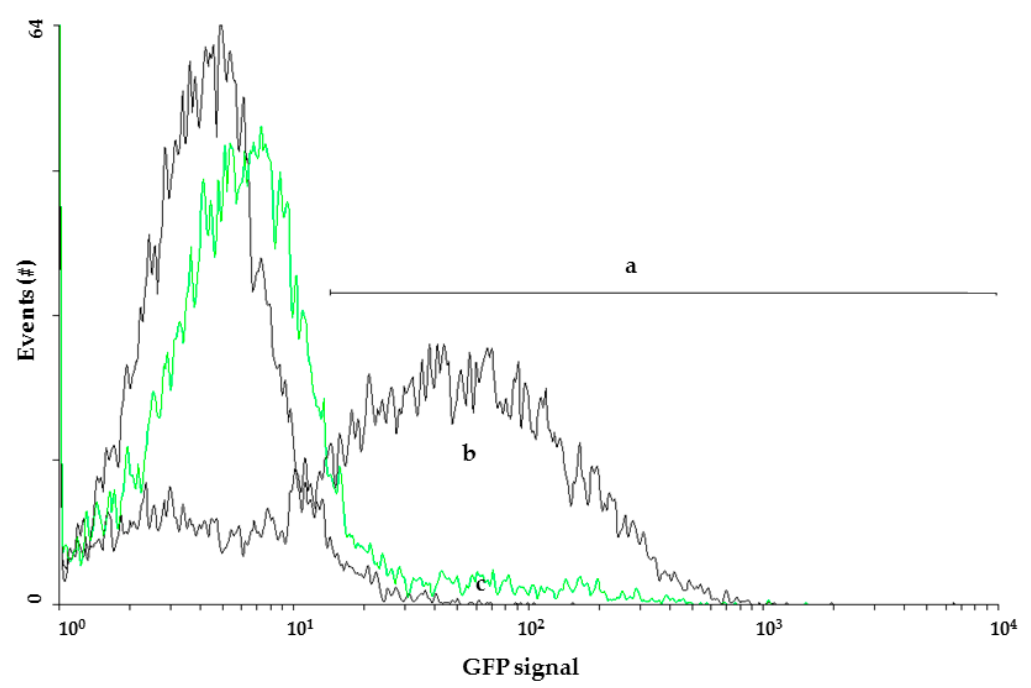

Figure 2. Flow cytometry analysis of GFP expressing parasites exposed to active and non-active $\mathrm{N}$-(halomethylated) ammonium salts, non $\mathrm{N}$-(halomethylated) ammonium salts and choline and halogenated cholines. The figure shows a representative fluorescence intensity signal from U-937 cells infected with $L$. (V) panamensis-pIR-eGFP exposed to any of the $N$-(halomethylated) ammonium salts, non $\mathrm{N}$-(halomethylated) ammonium salts and choline and halogenated cholines compound. (a) shift of the relative increase in the average fluorescence for $L$. (V) panamensis-pIR-eGFP compared to plain parasites; (b) black histogram represents the signal produced by Leishmania exposed to non active compounds and; (c) green histogram represents the signal produced by parasites exposed to active compounds. 


\subsubsection{In Vitro Leishmanicidal Activity with Axenic Amastigotes}

The ability of compounds to kill axenic amastigotes of $L .(V)$ panamensis was determined based on the viability of the parasites after exposure to each compound evaluated by the MTT method following the methodology described by others [26]. Axenic amastigotes obtained as described above were harvested, washed, and adjusted at $2 \times 10^{6}$ parasites $/ \mathrm{mL}$ in fresh Schneider's medium with $20 \%$ FBS. Into each well of a 96 -well plate $100 \mu \mathrm{L}$ of parasite suspension $\left(2 \times 10^{5}\right.$ axenic amastigotes $)$ were dispensed and then $100 \mu \mathrm{L}$ of each concentration of the corresponding compound were added. Four serial dilutions were prepared starting at $100 \mu \mathrm{g} / \mathrm{mL}(100,25,6.25$ and $1.56 \mu \mathrm{g} / \mathrm{mL})$. Plates were incubated at $32{ }^{\circ} \mathrm{C}$. After $72 \mathrm{~h}$ of incubation, the effect of each compound was determined by adding $10 \mu \mathrm{L} /$ well of MTT and incubating at $32^{\circ} \mathrm{C}$ for $3 \mathrm{~h}$. The reaction was stopped as described above and the quantity of formazan produced was measured in a plate reader spectrophotometer (Bio-Rad) set at $570 \mathrm{~nm}$. Axenic amastigotes cultivated in the absence of any compound but maintained under the same conditions were used as controls for growth and viability (negative control) while parasites cultivated in the presence of MA were used as controls for leishmanicidal activity (positive control). Assays were performed at least twice with three replicates per each concentration tested.

\subsubsection{Data Analysis}

Cytotoxicity was determined according to the percentages of cell growth (viability) obtained for each tested compound or medium alone. Percentages of viability were calculated first using Equation (1):

$$
\% \text { Viability }=(\text { O.D. of treated cells }) /(\text { O.D. of untreated cells }) \times 100
$$

where the O.D. of the untreated cells corresponds to $100 \%$ viability. Then, the percentage of cell growth inhibition was calculated using Equation (2):

$$
\% \text { Cell growth inhibition }=100-\% \text { Viability }
$$

Both \% viability and \% cell growth inhibition were used to calculate the Lethal Concentration $50\left(\mathrm{LC}_{50}\right)$ that corresponds to the concentration of drug that gives the half-maximal reduction of the cell growth using the Probit model [28]. The degree of cytotoxicity was established as convenient according to the $\mathrm{LC}_{50}$ values, using our own scale: high cytotoxicity: $\mathrm{LC}_{50}<100 \mu \mathrm{g} / \mathrm{mL}$, moderate cytotoxicity: $100 \mu \mathrm{g} / \mathrm{mL}<\mathrm{LC}_{50}<200 \mu \mathrm{g} / \mathrm{mL}$; and potential non-cytotoxicity: $\mathrm{LC}_{50}>200 \mu \mathrm{g} / \mathrm{mL}$.

The antileishmanial activity in intracellular amastigotes was determined according to the reduction of infected cells and parasite load (viable parasites inside infected cells) obtained for each experimental condition. The percentage of infected cell inhibition and parasite load for each concentration of each compound were calculated first using Equation (3):

$$
\% \text { infection }=(\% \text { infected and treated cells } \div \% \text { infected and untreated cells }) \times 100
$$

And then, the percentage of infection inhibition was calculated using Equation (4):

$$
\% \text { Inhibition }=100-\% \text { infection }
$$

In turn, activity of compounds with axenic amastigotes was determined according to the reduction of parasite growth percentages obtained for each experimental condition. The percentage of parasite growth was calculated first using Equation (5):

$\%$ parasite growth $=($ O.D. treated ax. amastigotes $) /($ O.D. of untreated ax. amastigotes $) \times 100$ 
where the O.D. of the untreated axenic amastigotes corresponds to $100 \%$ parasite growth. Then, the percentage of parasite growth inhibition was calculated using Equation (6):

$$
\% \text { parasite growth inhibition }=100-\% \text { parasite growth }
$$

The $\%$ of infection in U-937 cells and the \% of inhibition of axenic amastigotes growth were used to calculate the Effective Concentration $50\left(\mathrm{EC}_{50}\right)$ that corresponds to the concentration of drug that gives the half-maximal reduction of the infected cells and parasites using the Probit model [28]. The degree of leishmanicidal activity was also established as convenient according to the $\mathrm{EC}_{50}$ values, using our own scale: high leishmanicidal activity: $\mathrm{EC}_{50}<25 \mu \mathrm{g} / \mathrm{mL}$, moderate activity: $25 \mu \mathrm{g} / \mathrm{mL}<\mathrm{EC}_{50}<50 \mu \mathrm{g} / \mathrm{mL}$; and potential non-activity: $\mathrm{EC}_{50}>50 \mu \mathrm{g} / \mathrm{mL}$.

The Selectivity Index (SI) was calculated by comparing the cytotoxicity and the leishmanicidal activity using Equation (7):

$$
\mathrm{SI}=\mathrm{LC}_{50} / \mathrm{EC}_{50}
$$

\section{Conclusions}

Based on in vitro activity $\left(\mathrm{EC}_{50}, \mu \mathrm{g} / \mathrm{mL}\right)$ against $L .(V)$ panamensis, it was determined that the most active compound against $L$. (V) panamensis is compound $\mathbf{2} \mathbf{c}$, which has the longest carbon chain and a iodomethyl group on the nitrogen. When comparing the halomethylated salts $\mathbf{1}$ and $\mathbf{2}$ (series I) it is observed that their activity decreases with decreasing the carbon number of the salts that bear an iodomethyl group as a substituent, such that $\mathbf{2 c}$ is more effective than $\mathbf{2 b}$ and this, in turn, is more effective than 2a. On the other hand, as a general trend, the salts bearing an iodomethyl group are more effective against $L$. $(V)$ panamensis parasites than those bearing a chloromethyl group as a substituent. Currently, the structure-activity relationships via structural variations is being carried out.

Acknowledgments: This work was funded by Universidad de Caldas, Universidad de Antioquia (Codi-CIIEs) and Illinois State University.

Author Contributions: L.A.R.-V., S.M.R., D.L.C. and R.O.-C. conceived and designed the experiments; S.M.D.-B. and S.M.R. performed the experiments; L.A.R.-V., R.O.-C., S.M.D.-B., S.M.R., I.D.V., D.L.C., and M.A.J. analyzed the data and wrote the paper.

Conflicts of Interest: The authors declare no conflict of interest.

\section{Abbreviations}

The following abbreviations are used in this manuscript:

VL

ML

CL

MA

$\mathrm{AmB}$

$\mathrm{EC}_{50}$

$\mathrm{LC}_{50}$

FBS

NNN

PMA

RPMI

O.D.

THF

DMSO
Visceral leishmaniasis

Mucocutaneous leishmaniasis

Cutaneous leishmaniasis

Meglumine antimoniate

Amphotericin B

Effective Concentration 50

Lethal Concentration 50

Fetal Bovine Serum

Novy-MacNeal-Nicholle

Phorbol 12-myristate 13-acetate

Roswell Park Memorial Institute

Optical Density

Tetrahydrofuran

Dimethylsulfoxide 


\section{References}

1. World Health Organization. Investing to Overcome the Global Impact of Neglected Tropical Diseases: Third WHO Report on Neglected Diseases; WHO/HTM/NTD/2015.1; World Health Organization: Geneva, Swistzerland, 2015.

2. Alvar, J.; Vélez, I.D.; Bern, C.; Herrero, M.; Desjeux, P.; Cano, J.; Jannin, J.; den Boer, M.; WHO Leishmaniasis Control Team. Leishmaniasis worldwide and global estimates of its incidence. PLOS ONE 2012, 7, e35671.

3. Alvar, J.; Yactayo, S.; Bern, C. Leishmaniasis and poverty. Trends Parasitol. 2006, 22, 552-557. [CrossRef] [PubMed]

4. Kedzierski, L. Leishmaniasis vaccine: Where are we today? J. Glob. Infect. Dis. 2010, 2, 177-185. [CrossRef] [PubMed]

5. Den Boer, M.; Argaw, D.; Jannin, J.; Alvar, J. Leishmaniasis impact and treatment access. Clin. Microbiol. Infect. 2011, 17, 1471-1477. [CrossRef] [PubMed]

6. Yamey, G.; Torreele, E. The world's most neglected diseases. BMJ 2002, 325, 176-177. [CrossRef] [PubMed]

7. Ng, C.K.; Obando, D.; Widmer, F.; Wright, L.C.; Sorrell, T.C.; Jolliffe, C.K. Correlation of Antifungal Activity with Fungal Phospholipase Inhibition Using a Series of Bisquaternary Ammonium Salts. J. Med. Chem. 2006, 49, 811-816.

8. Calvani, M.; Critelli, L.; Gallo, G.; Giorgi, F.; Gramiccioli, G.; Santaniello, M.; Scafetta, N.; Tinti, M.; de Angelis, F. L-Carnitine Esters as Soft, Broad-Spectrum Antimicrobial Amphiphiles. J. Med. Chem. 1998, 41, 2227-2233. [CrossRef] [PubMed]

9. Shiraishi, M.; Aramak, Y.; Seto, M.; Imoto, H.; Nishikawa, Y.; Kanzaki, N.; Okamoto, M.; Sawada, H.; Nishimura, O.; Baba, M.; et al. Discovery of Novel, Potent, and Selective Small-Molecule CCR5 Antagonists as Anti-HIV-1 Agents: Synthesis and Biological Evaluation of Anilide Derivatives with a Quaternary Ammonium. J. Med. Chem. 2000, 43, 2049-2063. [PubMed]

10. Calas, M.; Cordina, G.; Bompart, J.; Ben Bari, M.; Jei, T.; Ancelin, M.L.; Vial, H. Antimalarial Activity of Molecules Interfering with Plasmodium falciparum Phospholipid Metabolism. Structure-Activity Relationship Analysis. J. Med. Chem. 1997, 40, 3557-3566. [PubMed]

11. Avlonitis, N.; Lekka, E.; Detsi, A.; Koufaki, M.; Calogeropoulou, T.; Scoulica, E.; Siapi, E.; Kyrikou, I.; Mavromoustakos, T.; Tsotinis, A.; et al. Antileishmanial Ring-Substituted Ether Phospholipids. J. Med. Chem. 2003, 46, 755-767.

12. Pérez, J.; Castanys, S.; Gamorro, F. Leishmania donovani Resistance to Miltefosine Involves a Defective Inward Translocation of the Drug. Antimicrob. Agents Chemother. 2003, 47, 2397-2403. [CrossRef]

13. Unger, C.; Sindermann, H.; Peukert, M.; Hilgard, P.; Engel, J.; Eibl, H. Hexadecylphosphocholine in the topical treatment of skin metastases in breast cancer patients. Prog. Exp. Tumor Res. 1992, 34, 153-159. [CrossRef]

14. Croft, S.L.; Yardley, V. Chemotherapy of leishmaniasis. Curr. Pharm. Des. 2002, 8, 319-342. [CrossRef] [PubMed]

15. Zufferey, R.; Mamoun, C.B. Choline transport in Leishmania major promastigotes and its inhibition by choline and phosphocholine analogs. Mol. Biochem. Parasitol. 2002, 125, 127-134. [CrossRef]

16. Boumann, H.A.; Damen, M.J.A.; Versluis, C.; Heck, A.J.R.; de Kruijff, B.; de Kroon, A.I. The two biosynthetic routes leading to phosphatidylcholine in yeast produce different sets of molecular species. Evidence for lipid remodeling. Biochemistry 2003, 42, 3054-3059. [PubMed]

17. Azzou, S.; Maache, M.; García, R.G.; Osuna, A. Leishmanicidal activity of edelfosine, miltefosine, and ilmofosine. Basic Clin. Pharmacol. Toxicol. 2005, 96, 60-65. [CrossRef] [PubMed]

18. Taylor, V.M.; Muñoz, D.L.; Cedeño, D.L.; Vélez, I.D.; Jones, M.A.; Robledo, S.M. Leishmania tarentolae: Utility as an in vitro model for screening of antileishmanial agents. Exp. Parasitol. 2010, 126, 471-475.

19. Ancelin, M.L.; Vial, H.J. Quaternary ammonium compounds efficiently inhibit Plasmodium falciparum growth in vitro by impairment of choline transport. Antimicrob. Agents Chemother. 1986, 29, 814-820. [CrossRef] [PubMed]

20. Múnera-Orozco, C.; Ocampo-Cardona., R.; Cedeño, D.L.; Toscano, R.A.; Ríos-Vásquez, L.A. Crystal structures of three new N-halomethylated quaternary ammonium salts. Acta Cryst. 2015, E71, 1230-1235.

21. Ríos, L.A.; Ocampo, R.; Duque, S.M.; Robledo, S.M.; Vélez, I.D.; Cedeño, D.L.; Jones, M.A. Quaternary N-(Halomethyl) Ammonium Salts as Therapeutic Agents. Patent US 9145352 B2, 29 September 2015. 
22. Sangshetti, J.N.; Khan, F.A.K.; Kulkarni, A.A.; Arote, R.; Patil, R.H. Antileishmanial drug discovery: Comprehensive review of the last 10 years. RSC Adv. 2015, 5, 32376-32415. [CrossRef]

23. Horner, J.; Martínez, F.; Musa, O.; Newcomb, M.; Shahin, H.E. Kinetics of Dialkylaminium Cation Radical Reactions: Radical Clocks, Solvent Effects, Acidity Constants, and Rate Constants for Reactions with Hydrogen Atom Donors. J. Am. Chem. Soc. 1995, 117, 11124-11133. [CrossRef]

24. Ríos, L.A.; Dolbier, W.R.; Paredes, R.; Lusztyk, J.; Ingold, K.U.; Jonsson, M. Generation and Study of the Reactivity of $\alpha$-Ammonium Distonic Radical Cations in Solution. J. Am. Chem. Soc. 1996, 118, 11313-11314. [CrossRef]

25. Mistry, J.S.; Abraham, D.J.; Kozikowski, A.P.; Hanin, I. Neurochemistry of Aging. 2. Design, Synthesis, and Biological Evaluation of Halomethyl Analogues of Choline with High Affinity Choline Transport Inhibitory Activity. J. Med. Chem. 1991, 34, 2031-2036. [PubMed]

26. Taylor, V.M.; Cedeño, D.L.; Muñoz, D.L.; Jones, M.A.; Lash, T.D.; Young, A.M.; Constantin, M.H.; Esposito, N.; Vélez, I.D.; Robledo, S.M. In Vitro and in Vivo Studies of the Utility of Dimethyl and Diethyl Carbaporphyrin Ketals in Treatment of Cutaneous Leishmaniasis. Antimicrob. Agents Chemother. 2011, 55, 4755-4764. [CrossRef] [PubMed]

27. Pulido, S.A.; Muñoz, D.L.; Restrepo, A.M.; Mesa, C.V.; Alzate, J.F.; Vélez, I.D.; Robledo, S.M. Improvement of the green fluorescent protein reporter system in Leishmania spp. for the in vitro and in vivo screening of antileishmanial drugs. Acta Trop. 2012, 122, 36-45. [PubMed]

28. Finney, J.D. Statistical Method in Biological Assay, 3rd ed.; Charles Griffin \& Co.: London, UK, 1978; p. 508.

Sample Availability: Samples of compounds $\mathbf{1 a}, \mathbf{1 b}, \mathbf{1 c}, \mathbf{2 a}, \mathbf{2 b}, \mathbf{2 c}, \mathbf{3 a}, \mathbf{3 b}$ and $\mathbf{3 c}$ are available from the authors. 